\title{
УДК 629.463.3:656.211.7
}

\section{А. О. ЛОВСЬКА ${ }^{1 *}$}

1*Каф. «Вагони», Український державний університет залізничного транспорту, пл. Фейєрбаха, 7, Харків, Україна, 61050, тел. +38 (057) 73010 35, ел. пошта alyonalovskaya.vagons@ gmail.com, ORCID 0000-0002-8604-1764

\section{ВИЗНАЧЕННЯ СТІЙКОСТІ КОНТЕЙНЕРА-ЦИСТЕРНИ ВІДНОСНО РАМИ ВАГОНА-ПЛАТФОРМИ ПІД ЧАС ПЕРЕВЕЗЕННЯ НА ЗАЛІЗНИЧНОМУ ПОРОМІ}

Мета. Це дослідження спрямоване на виявлення особливостей визначення стійкості контейнерацистерни відносно рами вагона-платформи, під час перевезення на залізничному поромі. Методика. Для досягнення зазначеної мети проведено математичне моделювання динамічної навантаженості контейнерацистерни, розміщеного на вагоні-платформі, під час перевезень на залізничному поромі. Модель враховує переміщення контейнера-цистерни відносно рами вагона-платформи та наливного вантажу в котлі, переміщення якого обмежені його стінками. Ураховано, що вагон-платформа, на якому розміщений контейнерцистерна, жорстко закріплений відносно палуби залізничного порома та здійснює переміщення разом із нею. За прототип обраний контейнер-цистерна типорозміру $1 \mathrm{CC}$, розміщений на вагоні-платформі моделі 13-4012. Під час складання моделі враховано трохоїдальний закон руху збуреної дії (морської хвилі) на залізничний пором із вагонами, розміщеними на його палубах, і дисипативну складову, яка виникає під час коливань залізничного порома в умовах морської хитавиці. Також взяті до уваги курсові кути морської хвилі відносно корпуса залізничного порома й вітрове навантаження, що діє на надводну проекцію залізничного порома, вагона-платформи, розміщеного на верхній палубі, і контейнерів-цистерн. Розв'язання диференціальних рівнянь руху здійснено в середовищі програмного забезпечення MathCad iз урахуванням зведення їх до нормальної форми Коші з наступним інтегруванням за методом Рунге-Кутта. Результати. Установлені величини прискорень як складові динамічного навантаження враховано під час дослідження стійкості контейнера-цистерни відносно рами вагона-платформи. Отримано уточнені величини динамічних навантажень, які діють на контейнер-цистерну, розміщену на вагоні-платформі, під час перевезення на залізничному поромі. Наукова новизна. Розроблено математичну модель переміщень контейнера-цистерни, розміщеного на вагоні-платформі, під час перевезення на залізничному поромі. Практична значимість. Результати проведених досліджень можуть бути використані під час проектування контейнерів-цистерн нового покоління 3 поліпшеними техніко-економічними й екологічними показниками.

Ключові слова: контейнер-цистерна; динаміка; стійкість; моделювання; навантаженість конструкції; залізнично-поромні перевезення

\section{Вступ}

Підвищення об'ємів перевезень наливних вантажів через міжнародні транспортні коридори зумовлює впровадження в експлуатацію контейнерів-цистерн. Потреба в контейнерахцистернах як транспортних засобах у перевізному процесі зумовлена їх мобільністю та інтермодальністю.

Останнім часом простежується ефективність експлуатації контейнерів і на залізничнопоромних маршрутах у складі поїздів комбінованого транспорту.

Для гарантування безпеки слідування контейнерів-цистерн морем необхідним $є$ дослі- дження їх стійкості під час коливань залізничного порома в умовах хвилювання моря.

Визначення динамічної навантаженості контейнера-цистерни за експлуатаційних режимів навантаження проведено у [29]. Отримані величини враховано під час розрахунків на міцність контейнера-цистерни в середовищі програмного забезпечення Ansys.

Особливості розрахунку на міцність підлоги 40-футового контейнера у програмному комплексі Abaqus/CAE v 6.1 наведені у [25]. Запропоновані рекомендації щодо безпечної експлуатації цього типу контейнера. 
Задача визначення показників міцності контейнерів під час перевезення їх на залізничних поромах у розглянутих роботах не ставилася.

Обгрунтування оптимізації несучої конструкції контейнера-цистерни моделі ТК25 з метою зменшення матеріалоємності наведене у $[5,20]$. Під час складання моделі міцності контейнерацистерни враховано, що конструкція повинна витримувати дію власних сил інерції. Ці сили виникають під час руху транспортного засобу, а також у ряді інших випадків: співударяння вагонів у момент маневрових операцій, у тому числі під час розпускання з гірок, екстреного гальмування в поїздах на малих швидкостях руху; за прискорень у повздовжньому напрямку $-2 \mathrm{~g}$, у поперечному напрямку $-1 \mathrm{~g}$, у вертикальному напрямку - 2g; у разі співударянь для завантаженого контейнера $-4 \mathrm{~g}$, для порожнього (з метою перевірки арматури) - 5g [4].

Дослідження міцності контейнера-цистерни моделі Т11 за експлуатаційних режимів навантаження проведене у [13]. У роботі проаналізований вплив густоти скінченно-елементної сітки на точність розрахунку напруженодеформованого стану контейнера-цистерни, а також проведені натурні дослідження його міцності за ударних навантажень.

Визначенню показників міцності контейнера-цистерни під час перевезення на залізничному поромі в цих роботах уваги не приділено.

Конструкційні особливості контейнерацистерни для перевезення та зберігання скрапленого природного газу розглянуті в [24]. У статті наведені теплові розрахунки котла контейнера-цистерни, визначений оптимальний час зберігання вантажу.

Вплив корозії й температури на міцність бокової оболонки паливного бака, що перебуває під тиском, досліджено у [28]. Запропоновані рекомендації щодо підвищення довговічності паливного бака в експлуатації.

Рекомендації щодо проектування несучих конструкцій контейнерів для забезпечення їх міцності під час перевезення на залізничних поромах у цих роботах не наведені.

Обгрунтування доцільності проектування та впровадження в експлуатацію контейнерівцистерн як транспортних засобів наведено в [15]. Розроблено нову оптимізовану констру- кцію контейнера-цистерни для перевезення світлих нафтопродуктів.

Результати визначення напруженого стану контейнера-цистерни наведені у [23], визначені відхилення рами й котла за експлуатаційних режимів навантаження.

Питанню дослідження міцності контейнерацистерни під час перевезення на залізничному поромі в зазначених роботах уваги не приділено.

Вплив рівня завантаження котла вагонацистерни наливним вантажем на його статичну навантаженість досліджено у [27]. У статті наведені результати визначення максимальних еквівалентних напружень i деформацій у котлі 3 урахуванням різного рівня його завантаженосTi.

Удосконалення конструкції опорного пристрою вагона-цистерни для перевезення наливних вантажів описано у [26]. Розрахунок на міцність проведений за методом скінченних елементів і реалізований в середовищі програмного забезпечення «Ліра».

Варіаційному описанню конструктивних виконань вантажних вагонів присвячена робота [21]. Наведені особливості й приклад застосування запропонованого методу формалізованих варіаційних описань конструктивних виконань вантажних вагонів у вигляді «І-АБО»- дерев.

Дослідження навантаженості несучих конструкцій транспортних засобів під час перевезення на залізничному поромі в цих роботах не проведене.

Визначення сил, які діють на вагони під час перевезень їх залізничним поромом морем проведене у [7]. При цьому динамічне навантаження, що діс на вагони, визначено шляхом диференціювання закону руху морської хвилі.

Особливості дослідження динамічних навантажень, які діють на вагони під час перевезень ïх морем, розглянуті у [11]. У роботі наведено математичні моделі, які дозволяють отримати прискорення за основних видів коливань залізничного порома.

Визначенню навантаженості контейнерівцистерн у складі поїздів комбінованого транспорту під час перевезень на залізничних поромах досі уваги не приділялося. 


\section{Мета}

Основною метою статті $€$ виявлення особливостей визначення стійкості контейнерацистерни відносно рами вагона-платформи під час перевезення на залізничному поромі. Для досягнення поставленої мети потрібно розв'язати наступні задачі:

1. Провести математичне моделювання динамічної навантаженості контейнера-цистерни, розміщеного на вагоні-платформі.

2. Визначити коефіцієнт стійкості контейнера-цистерни відносно рами вагона-платформи.

\section{Методика}

Для визначення динамічної навантаженості контейнера-цистерни під час перевезення у складі комбінованого поїзда на залізничному поромі складено математичну модель (1), яка враховує переміщення системи «залізничний пором - контейнер-цистерна - наливний вантаж» за кутових переміщень відносно поздовжньої осі (рис. 1). Модель враховує, що вагонплатформа, на якому розміщений контейнерцистерна, жорстко закріплений відносно палуби залізничного порома й здійснює переміщення разом із нею.

Розрахунки проведені стосовно залізничного порома «Герои Шипки», що рухається акваторією Чорного моря. За базову модель вагонаплатформи взята модель 13-4012.

Ударна дія морських хвиль на корпус залізничного порома 3 вагонами, розміщеними на його борту, до уваги не взята. Під час складання моделі враховано трохоїдальний закон руху збуреної дії $[10,12]$ (морської хвилі) на залізничний пором із вагонами, розміщеними на його палубах (2), і дисипативну складову, яка виникає під час коливань залізничного порома в умовах морської хитавиці. Також взяті до уваги курсові кути морської хвилі відносно корпуса залізничного порома $\left(\chi=0^{0}-180^{\circ}[17]\right)$ та вітрове навантаження, що діє на надводну проекцію залізничного порому, вагонаплатформи, розміщеного на верхній палубі, i контейнерів-цистерн. Чисельні значення параметрів збуреної дії, які закладені у математичну модель, наведені у табл. 1. При цьому до уваги взяті найбільш несприятливі гідрометео- рологічні параметри, характерні для руху залізничного порома морем і наведені у $[2,7]$.

Частоту морської хвилі визначено з урахуванням курсового кута до корпуса залізничного порома 3 вагонами, розміщеними на його палубax $[1,14]$ :

$$
\omega=\frac{2 \pi \cdot v}{k_{\lambda} \cdot L \cdot \cos \chi},
$$

де $v$ - швидкість руху залізничного порома; $k_{\lambda}$ - коефіцієнт, який залежить від форми обводів судна; $\chi$ - курсовий кут хвилі відносно корпуса залізничного порома.

Таблиця 1

Чисельні значення параметрів збуреної дії, які закладені у математичну модель

Table 1

Numerical values of the disturbing action parameters laid in the mathematical model

\begin{tabular}{|c|c|}
\hline Назва параметра & $\begin{array}{c}\text { Чисельне зна- } \\
\text { чення }\end{array}$ \\
\hline Висота морської хвилі, м & 8 \\
\hline Курсовий кут хвилі, град. & $0-180$ \\
\hline $\begin{array}{c}\text { Тиск вітру на надводну проекцію } \\
\text { залізничного порому, т/м² }\end{array}$ & 0,15 \\
\hline $\begin{array}{c}\text { Коефіцієнт опору кутовим пе- } \\
\text { реміщенням залізничного поро- } \\
\text { му відносно поперечної осі, } \\
\text { тсм }^{-1}\end{array}$ & 16 \\
\hline $\begin{array}{c}\text { Коефіцієнт опору кутовим пе- } \\
\text { реміщенням залізничного поро- } \\
\text { му відносно поздовжньої осі, } \\
\text { тсм}^{-1}\end{array}$ & 0,34 \\
\hline
\end{tabular}

Швидкість руху залізничного порома взята рівною його конструкційній швидкості 18,6 вузлів $(9,57$ м/с) та під час руху акваторією моря враховувалася незмінною.

Описання процесу переміщень контейнерацистерни 3 наливним вантажем здійснене за методикою, наведеною в [16].

Враховано, що вагон-платформа закріплений відносно палуби за типовою схемою 3 використанням ланцюгових стяжок із талрепами та упор-домкратами. Щоб уникнути перекочування вагонів відносно рейок, під поверхні ко- 
чення коліс установлені гальмівні башмаки, а в поздовжньому напрямку крайні в зчепах вагони з'єднані з тупиковими упорами, обладнаними стандартними автозчепами рухомого складу СА-3. Крім того, з метою загальмовування колісних пар гальмівна система вагона підключена до спеціальних рукавів системи для подачі стисненого повітря [19, 22].

Модель не враховує можливих переміщень вагона-платформи відносно палуби залізничного порома.

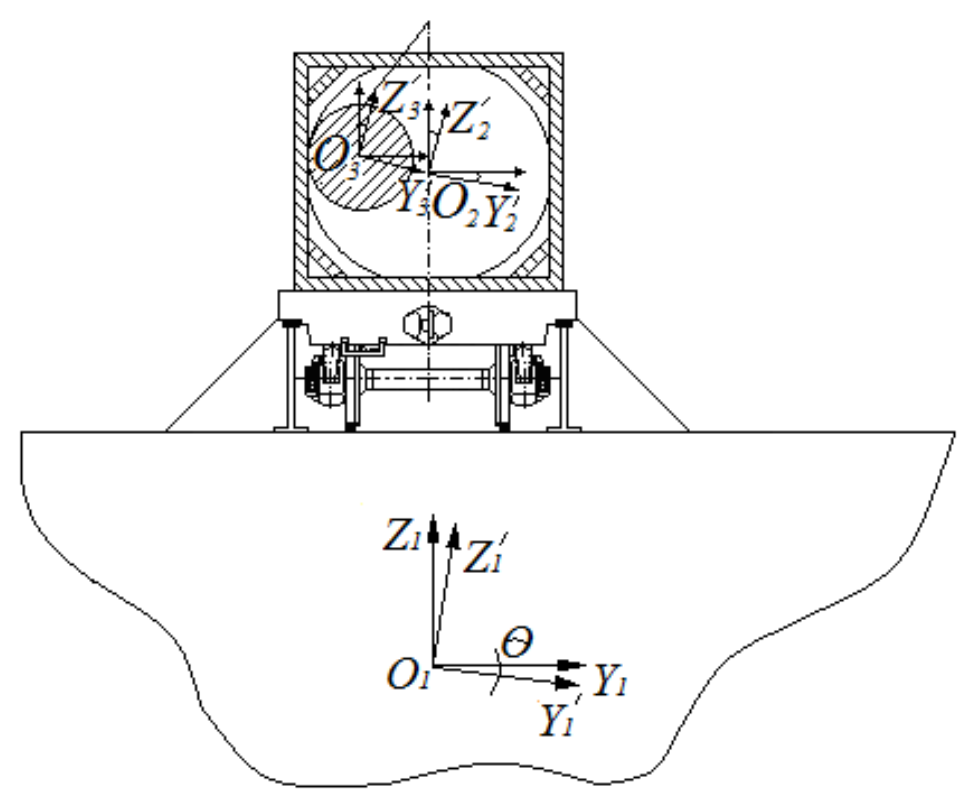

Рис. 1. Схема переміщень контейнера-цистерни з наливним вантажем під час коливань залізничного порома

Fig. 1. Scheme of displacements of a tank-container with liquid cargo during oscillations of a railway ferry

\section{Результати}

Математична модель визначення динамічної навантаженості контейнера-цистерни під час перевезення на залізничному поромі:

$$
\left\{\begin{array}{l}
\left(\frac{D}{12 \cdot g}\left(B^{2}+4 z_{g}{ }^{2}\right)\right) \ddot{q}+\left(\Lambda_{\theta} \cdot \frac{B}{2}\right) \dot{q}=p^{\prime} \cdot \frac{h}{2}+\Lambda_{\theta} \cdot \frac{B}{2} \cdot \dot{F}(t), \\
\left(I_{\theta i}+\sum_{j=1}^{k} m_{i j} \cdot c_{i j}^{2}\right) \cdot \ddot{\theta}_{2}+\sum_{j=1}^{k} m_{i j} \cdot c_{i j} \cdot l_{i j} \cdot \ddot{\theta}_{3}-g \cdot\left(m_{i} \cdot z_{c i}+\sum_{j=1}^{k} m_{i j} \cdot c_{i j}\right) \cdot \theta_{2}=F_{k}, \\
I_{i j} \cdot \ddot{\theta}_{3}-m_{i j} \cdot c_{i j} \cdot l_{i j} \cdot \ddot{\theta}_{2}+g \cdot m_{i j} \cdot l_{i j} \cdot \theta_{3}=0,
\end{array}\right.
$$

де $q_{1}=\theta_{1}, q_{2}=\theta_{2}, q_{3}=\theta_{3}-$ узагальнені координати, що відповідають кутовому переміщенню відносно поздовжньої осі залізничного порома, контейнера-цистерни й наливного вантажу відповідно; початок системи координат ро- зміщений у центрі мас залізничного порома; $D$ - вагове водовитіснення; $B$ - ширина залізничного порома; $h$ - висота борта залізничного порома; $\Lambda_{\theta}$ - коефіцієнт опору коливанням; 
$z_{g}$ - координата центру ваги залізничного порома; $p^{\prime}$ - вітрове навантаження; $F(t)-$ закон дії зусилля, яке збурює рух залізничного порома 3 вагонами, розміщеними на його палубах; $I_{i j}$ - момент інерції маятника; $m_{i j}$ - маса $j$-го маятника у $i$-му контейнері-цистерні; $c_{i j}-$ відстань від площини $z_{i}=0$ до точки закріплення $j$-го маятника у $i$-му контейнері-цистерні; $l_{i j}$ - довжина $j$-го маятника; $I_{\theta}-$ приведений момент інерції $i$-го контейнера-цистерни та наливного вантажу, що не бере участі в русі відносно котла; $z_{c i}-$ висота центру ваги контейнера-цистерни; $m_{i}$ - маса тіла, яке еквівалентне $i$-му контейнеру-цистерні 3 частиною наливного вантажу, що не бере участі в переміщенні відносно котла; $F_{k}$ - момент сил, що виникає між контейнером-цистерною та вагономплатформою.
За наливний вантаж узятий бензин. Визначення гідродинамічних характеристик наливного вантажу здійснене з урахуванням максимально допустимої завантаженості котла контейнера-цистерни - 95 \% від його загальної місткості відповідно до [18] та обраної, виходячи 3 умов забезпечення безпеки перевезень морем. Рух наливного вантажу описано сукупністю математичних маятників [16].

Розв'язання математичної моделі здійснено в середовищі програмного забезпечення MathCad $[6,8]$. При цьому вона зведена до нормальної форми Коші $\dot{y}(t)=Q(t, y)$.

Вирішення системи диференціальних рівнянь (1) у нормальній формі проведено інтегруванням за методом Рунге-Кутта.

При цьому: $y_{1}=\theta_{1}, y_{2}=\dot{\theta}_{1}$, $y_{3}=\theta_{2}, y_{4}=\dot{\theta}_{2}$, $y_{5}=\theta_{3}, y_{6}=\dot{\theta}_{3}$.

Тоді

$y_{2}$

$y_{4}$

$y_{6}$

$\frac{p^{\prime} \cdot \frac{h}{2}+\Lambda_{\theta} \cdot \frac{B}{2} \cdot \dot{F}(t)}{I}-\frac{\Lambda_{\theta} \cdot \frac{B}{2}}{I} \cdot y_{2}$

$Z(t, y)=\frac{-\left(\sum_{j=1}^{k} m_{i j} \cdot c_{i j} \cdot l_{i j}\right) \frac{d}{d t} y_{6}+g \cdot\left(m_{i} \cdot z_{c i}+\sum_{j=1}^{k} m_{i j} \cdot c_{i j}\right) \cdot y_{3}}{\left(I_{\theta i}+\sum_{j=1}^{k} m_{i j} \cdot c_{i j}^{2}\right)}+\frac{F_{k}}{\left(I_{\theta i}+\sum_{j=1}^{k} m_{i j} \cdot c_{i j}^{2}\right)}$

$$
\frac{\left(m_{i j} \cdot c_{i j} \cdot l_{i j}\right) \cdot \frac{d}{d t} y_{4}-\left(g \cdot m_{i j} \cdot l_{i j}\right) \cdot y_{5}}{I_{i j}}
$$

$$
Z=\operatorname{rkfixed}(Y 0, t n, t k, n, Q)
$$

де $Y O$ - вектор, який містить початкові умови, $t n, t k$ - величини, які визначають початкову й кінцеву змінну інтегрування, $n$ - фіксоване число кроків, $Q$ - символьний вектор.

Початкові умови взяті рівними нулю.

$$
\ddot{\theta}_{1}=\frac{p^{\prime} \cdot \frac{h}{2}+\Lambda_{\theta} \cdot \frac{B}{2} \cdot \dot{F}(t)}{I}-\frac{\Lambda_{\theta} \cdot \frac{B}{2}}{I} \cdot y_{2},
$$

Аналітичні вирази для визначення прискорень, які діють на залізничний пором (3), контейнер-цистерну (4) та наливний вантаж (5) наведені нижче: 


$$
\begin{gathered}
\ddot{\theta}_{2}=\frac{\left(\frac{g \cdot\left(m_{i} \cdot z_{c i}+\sum_{j=1}^{k} m_{i j} \cdot c_{i j}\right) \cdot y_{3}}{I_{\theta i}+\sum_{j=1}^{k} m_{i j} \cdot c_{i j}^{2}}+\frac{F_{k}}{I_{\theta i}+\sum_{j=1}^{k} m_{i j} \cdot c_{i j}^{2}}-\frac{g \cdot y_{3}}{c_{i j}} \cdot \frac{m_{i j} \cdot c_{i j} \cdot l_{i j} \cdot\left(I_{\theta i}+\sum_{j=1}^{k} m_{i j} \cdot c_{i j}^{2}\right)}{m_{i j} \cdot\left(I_{\theta i}+\sum_{j=1}^{k} m_{i j} \cdot c_{i j}^{2}\right)+\left(m_{i j} \cdot c_{i j} \cdot l_{i j}\right)^{2}}\right) \cdot I_{i j}+}{\frac{+g \cdot m_{i j} \cdot l_{i j} \cdot y_{5}}{I_{\theta i}+\sum_{j=1}^{k} m_{i j} \cdot c_{i j}^{2}},}, \frac{g \cdot y_{3}}{c_{i j}} \cdot \frac{m_{i j} \cdot c_{i j} \cdot l_{i j} \cdot\left(I_{\theta i}+\sum_{j=1}^{k} m_{i j} \cdot c_{i j}^{2}\right)}{I_{i j} \cdot\left(I_{\theta i}+\sum_{j=1}^{k} m_{i j} \cdot c_{i j}^{2}\right)+\left(m_{i j} \cdot c_{i j} \cdot l_{i j}\right)^{2}} .
\end{gathered}
$$

На підставі проведених розрахунків отримано прискорення, які діють на контейнерцистерну, розміщену на вагоні-платформі під час перевезення на залізничному поромі (рис. 2). При цьому кожному кольору кривої відповідає величина прискорення, яка отримана

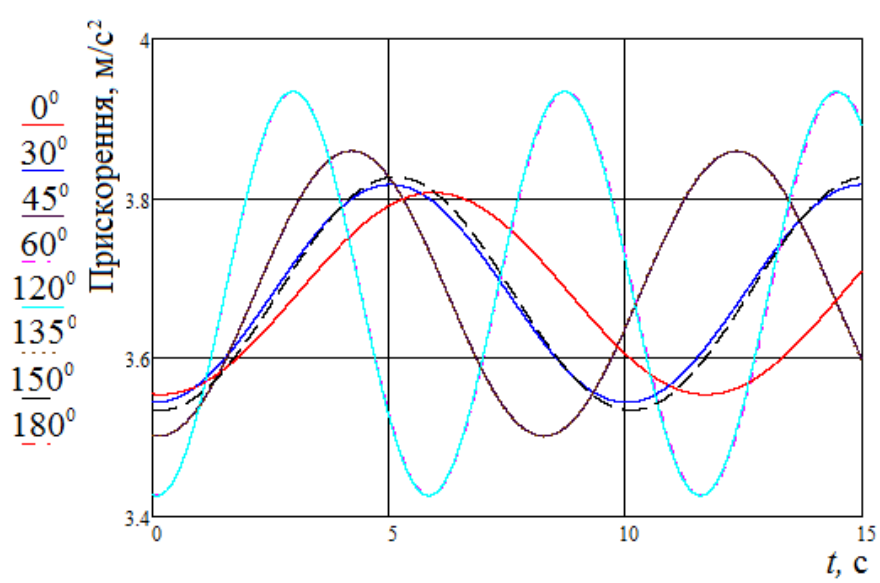

Рис. 2. Прискорення, які діють на контейнер-цистерну

Fig. 2. Accelerations acting on a tank-container

Результати досліджень дозволили зробити висновок, що максимальні прискорення, які діють на контейнер-цистерну, складають близько 3,8 м/с $\mathrm{c}^{2}$ (рис. 2). 3 урахуванням горизонтальної складової прискорення вільного падіння, обумовленої кутом нахилу залізничного порома, загальна величина прискорення складе $5,87 \mathrm{~m} / \mathrm{c}^{2}(0,6 \mathrm{~g})$. Тобто величина прискорення, яке діє на контейнер-цистерну, перевищує нормативну для одиниць рухомого складу й ванта- для певного курсового кута хвилі відносно корпуса залізничного порома 3 вагонами, розміщеними на ньому (підписи кутів наведені збоку осі ординат). жів під час перевезень на залізничному поромі, що становить $4,91 \mathrm{~m} / \mathrm{c}^{2}(0,5 \mathrm{~g})$ за кута крену $30^{\circ}$ [3]. Отже, за розрахункового кута крену $12,2^{\circ}$, який визначений $з$ урахуванням гідрометеорологічних умов акваторії Чорного моря, величина прискорення вже на $16 \%$ перевищує нормативну.

Для забезпечення стійкості рівноваги контейнера-цистерни відносно рами вагонаплатформи потрібно виконувати умову [9]: 


$$
k_{c}=\frac{M_{\text {вidн }}}{M_{\text {nep }}} \geq 1,
$$

де $M_{\text {відн }}$ - величина відновного моменту; $M_{\text {пер }}$ - величина перекидного моменту.

$$
\begin{gathered}
M_{n е p}=p_{k}^{\prime} \cdot \frac{h_{\kappa}}{2}+M_{\sigma p} \cdot\left(g \cdot \sin \theta+\ddot{\theta}_{2}\right) \cdot \frac{h_{\kappa}}{2}, \\
M_{\text {відн }}=P_{\sigma p} \cdot \cos \theta \cdot \frac{B_{\kappa}}{2}+ \\
\quad+n_{\phi} \cdot\left(M_{\sigma р} \cdot\left(g \cdot \sin \theta+\ddot{q}_{k}\right)\right) \cdot \frac{h_{\phi}}{2},
\end{gathered}
$$

де $M_{\text {бр }}-$ маса брутто контейнера-цистерни; $P_{\text {бр }}$ - вага брутто контейнера-цистерни; $B_{\kappa}-$ ширина контейнера-цистерни; $n_{\phi}-$ кількість фітингових упорів, на які обпирається контейнер-цистерна за кутових переміщень відносно поздовжньої осі; $h_{\phi}$ - висота фітингового упора.

На підставі проведених розрахунків побудовано графічну залежність коефіцієнта стійкості контейнера-цистерни відносно рами вагонаплатформи від кута крену залізничного порома (рис. 3). Крива стійкості позначена синім кольором, лінію тренду (чорний колір) при цьому можна описати рівнянням $y=2,2896 \cdot e^{-0,175 x}$.

Iз рис. 3 видно, що стійкість контейнерацистерни відносно рами вагона-платформи забезпечується за кутів крену залізничного порома до $12^{\circ}$.

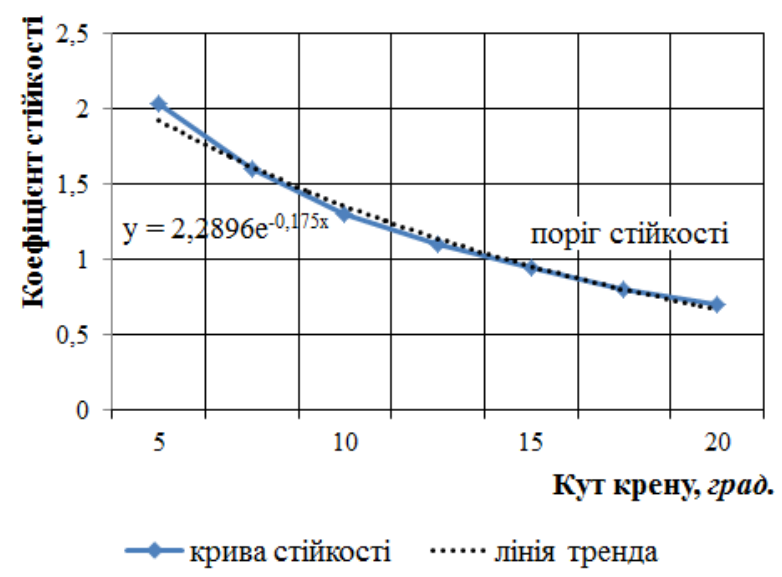

Рис. 3. Залежність коефіцієнта стійкості контейнера-цистерни від кута крену залізничного порома

Fig. 3. Dependence of the stability coefficient of a tank-container on the rolling angle of the railway ferry

Отримані в ході досліджень результати дозволили визначити динамічну навантаженість контейнера-цистерни, розміщеного на вагоніплатформі, під час перевезення залізничним поромом. Визначено кут крену, за якого забезпечується стійкість контейнерів-цистерн відносно рами вагона-платформи під час перевезень на залізничному поромі 3 урахуванням типової схеми взаємодії контейнерів-цистерн із рамою. Це сприятиме створенню рекомендацій щодо безпечної експлуатації контейнерівцистерн для комбінованих залізничнопоромних перевезень і розробці нової схеми

Creative Commons Attribution 4.0 Internationa взаємодії контейнерів-цистерн із рамою вагонів-платформ.

Також отримані результати дозволять на стадії проектування контейнерів-цистерн в умовах вагонобудівних підприємств враховувати уточнені величини навантажень, які діють на них під час експлуатації не тільки відносно магістральних колій, а й на залізничних поромах.

\section{Наукова новизна та практична значимість}

Розроблено математичну модель переміщень контейнера-цистерни, розташованого на вагоні-платформі, під час перевезень на заліз- 
ничному поромі. Модель враховує коливання наливного вантажу в котлі, яке описувалося маятником, й контейнера-цистерни відносно рами вагона-платформи, обумовлену наявністю зазорів між фітинговими упорами та фітингами.

Результати проведених досліджень можуть бути використані під час проектування контейнерів-цистерн нового покоління 3 поліпшеними техніко-економічними й екологічними показниками.

\section{Висновки}

1. Проведено математичне моделювання динамічної навантаженості контейнера-цистерни, розміщеного на вагоні-платформі, під час пере- везення на залізничному поромі. Установлено, що 3 урахуванням горизонтальної складової прискорення вільного падіння, обумовленої кутом нахилу залізничного порома, загальна величина прискорення, яке діє на контейнерцистерну, складає 5,87 м/ ${ }^{2}(0,6 \mathrm{~g})$.

2. Досліджено стійкість контейнерацистерни відносно рами вагона-платформи, під час перевезення на залізничному поромі. При цьому стійкість контейнера-цистерни відносно рами вагона-платформи забезпечується за кутів крену залізничного порома до $12^{0}$.

3. Проведені дослідження сприятимуть підвищенню ефективності комбінованих перевезень через міжнародні транспортні коридори.

\section{СПИСОК ВИКОРИСТАНИХ ДЖЕРЕЛ}

1. Благовещенский, С. Н. Справочник по статике и динамике корабля : в 2 т. / С. Н. Благовещенский, А. Н. Холодилин. - 2-е изд., перераб. и доп. - Ленинград : Судостроение, 1975. - Т. 2 : Динамика (качка) корабля. $-176 \mathrm{c}$.

2. Ветер и волны в океанах и морях : справ. данные. - Ленинград : Транспорт, 1974. - 359 с.

3. ГОСТ 33211-2014. Вагоны грузовые. Требования к прочности и динамическим качествам. - Москва : Стандартинформ, 2016. - $54 \mathrm{c}$.

4. ГОСТ 31232-2004. Контейнеры для перевозки опасных грузов. Требования по эксплуатационной безопасности. - Минск : Госстандарт Республики Беларусь, 2005. - 6 с.

5. Дослідження міцності контейнера-цистерни удосконаленої конструкції при комп'ютерному моделюванні експлуатаційних умов / А. О. Ловська, О. В. Фомін, А. М. Окороков, О. М. Мельничук // Наука та прогрес транспорту. - 2015. - № 2 (56). - С. 180-188. doi: 10.15802/stp2015/42177

6. Дьяконов, В. MATHCAD 8/2000 : спец. справ. / В. Дьяконов. - Санкт-Петербург : Питер, 2000. - 592 с.

7. Землезин, И. Н. Методика расчета и исследования сил, действующих на вагон при транспортировке на морских паромах / И. Н. Землезин. - Москва : Транспорт, 1970. - 104 с.

8. Кирьянов, Д. В. Mathcad 13 / Д. В. Кирьянов. - Санкт-Петербург : БХВ-Петербург, 2006. - 608 с.

9. Ловська, А. О. Визначення навантаженості контейнерів у складі комбінованих поїздів при перевезенні залізничним поромом / А. О. Ловська // Наука та прогрес транспорту. - 2017. - № 6 (72). - С. 49-60. doi: $10.15802 /$ stp2017/118993

10. Ловська, А. О. Моделювання навантаженості контейнера-цистерни при перевезенні у складі комбінованого поїзда на залізничному поромі / А. О. Ловська // Вісн. Нац. техн. ун-ту «ХПІ». Серія: Динаміка і міцність машин : $\quad$ зб. наук. пр. - Харків, 2018. - Вип. 33. - С. 28-32. doi: $10.20998 / 2078-9130.2018 .33 .151225$

11. Ловська, А. О. Особливості математичного моделювання динаміки кузовів вагонів при їх перевезенні на залізничних поромах / А. О. Ловська // Зб. наук. пр. Донец. ін-ту залізн. трансп. - Донецьк, 2014. Вип. 37 - С. 84-93.

12. Луговский, В. В. Динамика моря: избранные вопросы, связанные с учением мореходности корабля : учебник для втузов / В. В. Луговский. - Ленинград : Судостроение, 1976. - 199 с.

13. Макеев, С. В. Особенности расчета напряженно-деформированного состояния танка-контейнера с учетом реального нагружения в эксплуатации / С. В. Макеев, П. М. Буйленков // Наука-образованиепроизводство: опыт и перспективы развития : сб. материалов XIV Междунар. науч.-техн. конф., посв. памяти Е. Г. Зудова (8-9 февр. 2018 г.) : в 2-х т. - Нижний Тагил, 2018. - Т. 1 : Горно-металлургическое производство. Машиностроение и металлообработка. - С. 174-184.

14. Маков, Ю. Л. Качка судов : учеб. пособие / Ю. Л. Маков. - Калининград : Изд-во ФГОУ ВПО «КГТУ», 2007. $-321 \mathrm{c}$. 
15. Мямлин, С. В. Перспективные конструкции контейнеров-цистерн для перевозки светлых нефтепродуктов, аммиака и углеводородных газов / С. В. Мямлин, Ю. В. Кебал, С. М. Кондратюк // Залізн. трансп. України. - 2012. - № 2. - С. 44-46.

16. Нагруженность контейнеров-цистерн, расположенных на железнодорожной платформе, при ударах в автосцепку / Г. И. Богомаз, Д. Д. Мехов, О. П. Пилипченко, Ю. Г. Черномашенцева // Динаміка та керування рухом механічних систем : зб. наук. пр. / АНУ, ін-т техн. механіки. - Київ, 1992. - С. 87-95.

17. Наставление по креплению груза для т/х «Петровск». ПР № 002CNF001-ЛМПЛ-805. - Одесса : МИБ, 2005. $-52 \mathrm{c}$.

18. Правила перевозок опасных грузов. К соглашению о международном железнодорожном грузовом сообщении (СМГС) [Електронний ресурс] // Организация Сотрудничества Железных Дорог (ОСЖД). 2011. - 531 с. - Режим доступу: http://docs.cntd.ru/document/902061479 - Назва з екрана. - Перевірено : 06.02.2019.

19. Международная паромная переправа Ильичевск - Варна / А. Е. Суколенов, Э. Захариев, И. Г. Гутин [и др.] ; под ред. А. Е. Суколенова. - Москва : Транспорт, 1989. - 103 с.

20. Ловська, А. О. Удосконалення контейнерів-цистерн для перевезення нафтопродуктів шляхом впровадження в їх несучі конструкції круглих труб / А. О. Ловська, О. М. Мельничук, О. В. Фомін // Залізн. трансп. України. - 2015. - № 1. - С. 40-44.

21. Фомін, О. В. Варіаційне описання конструктивних виконань вантажних вагонів / О. В Фомін, А. В. Гостра // Зб. наук. пр. Держ. економ.-технолог. ун-ту трансп. Серія: «Транспортні системи і технології». Київ, 2015. - Вип. 26-27. - С. 137-147.

22. Шмаков, М. Г. Специальные судовые устройства : справ. пособие / М. Г. Шмаков. - Ленинград : Судостроение, 1975. - 344 с

23. Bhattacharyya, R. A study on Stress analysis of ISO tank container [Електронний pecypc] / R. Bhattacharyya, A. Hazra // 58th Congress of the Indian Society of Theoretical and Applied Mechanics : Conference Paper. 2013. - Режим доступу: https://clck.ru/F9TYb - Назва з екрана. - Перевірено : 05.02.2019.

24. Lisowski, E. Transport and storage of LNG in container tanks / E. Lisowski, W. Czyİycki // Journal of KONES Powertrain and Transport. - 2011. - Vol. 18, No. 3. - P. 193-201.

25. Rzeczycki, A. Strength Analysis of Shipping Container Floor with Gooseneck Tunnel under Heavy Cargo Load / A. Rzeczycki, B. Wisnicki // Solid State Phenomena. - 2016. - Vol. 252. - P. 81-90. doi: 0.4028/www.scientific.net/ssp.252.81

26. Structural Improvements in a Tank Wagon with Modern Software Packages / G. Vatulia, A. Falendysh, Y. Orel, M. Pavliuchenkov // Procedia Engineering. - 2017. - Vol. 187. - P. 301-307. doi: 10.1016/j.proeng.2017.04.379

27. Study of the effect of liquid level on the static behavior of a tank wagon / J. O. Trejo-Escandón, A. LeyvaDíaz, P. A. Tamayo-Meza, L. A. Flores-Herrera, J. M. Sandoval-Pineda // International Journal of Engineering Research and Science and Technology. - 2015. - Vol. 4, No. 1. - P. 18-25.

28. Talu, M. The Influence of the Corrosion and Temperature on the Von Mises Stress in the Lateral Cover of a Pressurized Fuel Tank / M. Talu // Hidraulica. - 2017. - Iss. 4. - P. 89-97.

29. Tiernan, S. Dynamic FEA modeling of ISO tank containers / S. Tiernan, M. Fahy // Journal of Materials Processing Technology. - 2002. - Vol. 124. - Iss. 1-2. - P. 126-132. doi: 10.1016/s0924-0136(02)00196-6

\section{А. А. ЛОВСКАЯ ${ }^{1 *}$}

1 Каф. «Вагоны», Украинский государственный университет железнодорожного транспорта, пл. Фейербаха, 7, Харьков, Украина, 61050, тел. +38 (057) 73010 35, эл. почта alyonalovskaya.vagons@ gmail.com, ORCID 0000-0002-8604-1764

\section{ОПРЕДЕЛЕНИЕ УСТОЙЧИВОСТИ КОНТЕЙНЕРА-ЦИСТЕРНЫ ОТНОСИТЕЛЬНО РАМЫ ВАГОНА-ПЛАТФОРМЫ ПРИ ПЕРЕВОЗКЕ НА ЖЕЛЕЗНОДОРОЖНОМ ПАРОМЕ}

Цель. Данное исследование направлено на выявление особенностей определения устойчивости контейнера-цистерны относительно рамы вагона-платформы при перевозке на железнодорожном пароме. Методика. Для достижения поставленной цели проведено математическое моделирование динамической 
нагруженности контейнера-цистерны, размещенного на вагоне-платформе, при перевозке на железнодорожном пароме. Модель учитывает перемещение контейнера-цистерны относительно рамы вагона-платформы и наливного груза в котле, перемещения которого ограничены его стенками. При этом принято допущение, что вагон-платформа, на котором размещен контейнер-цистерна, жестко закреплен относительно палубы железнодорожного парома и осуществляет перемещения вместе с ней. В качестве прототипа выбран контейнер-цистерна типоразмера 1CC, размещенный на вагоне-платформе модели 13-4012. При составлении модели учтено трохоидальный закон движения возмущающего воздействия (морской волны) на железнодорожный паром с вагонами, размещенными на его палубах, и диссипативную составляющую, которая возникает при колебаниях железнодорожного парома в условиях морской качки. Также приняты во внимание курсовые углы морской волны по отношению к корпусу железнодорожного парома и ветровая нагрузка, действующая на надводную проекцию железнодорожного парома, вагона-платформы, расположенного на верхней палубе, и контейнеров-цистерн. Решение дифференциальных уравнений движения осуществлено в среде программного обеспечения MathCad с учетом сведения их к нормальной форме Коши с последующим интегрированием по методу Рунге-Кутта. Результаты. Установленные величины ускорений как составляющие динамической нагрузки учтены при исследовании устойчивости контейнера-цистерны относительно рамы вагона-платформы. Получены уточненные величины динамических нагрузок, действующих на контейнер-цистерну, размещенного на вагоне-платформе, при перевозке на железнодорожном пароме. Научная новизна. Разработана математическая модель перемещений контейнера-цистерны, размещенного на вагоне-платформе, при перевозке на железнодорожном пароме. Практическая значимость. Результаты проведенных исследований могут быть использованы при проектировании контейнеров-цистерн нового поколения с улучшенными технико-экономическими и экологическими показателями.

Ключевые слова: контейнер-цистерна; динамика; устойчивость; моделирование; нагруженность конструкции; железнодорожно-паромные перевозки

\section{A. O. LOVSKA ${ }^{1 *}$}

1*Dep. «Cars», Ukrainian State University of Railway Transport, Feuerbach Sq., 7, Kharkiv, Ukraine, 61050, tel. +38 (057) 73010 35, e-mail alyonalovskaya.vagons@gmail.com, ORCID 0000-0002-8604-1764

\section{DETERMINATION OF THE TANK CONTAINER STABILITY RELATIVE TO THE FRAME OF A FLAT CAR DURING TRAIN FERRY TRANSPORTATION}

Purpose. The research is aimed at revealing the peculiarities of stability determination for a tank container relative to the frame of a flat car during transportation by train ferry. Methodology. In order to reach the purpose, the mathematical modelling of dynamic loading of a tank container located on a flat car during the train ferry transportation was conducted. The model takes into account the tank container displacements relative to the flat car frame and liquid cargo in the tank, the displacements of which are limited by the tank's walls. It was assumed that the flat car, with tank container on it, was rigidly fixed relative to the deck of the train ferry and moved together with it. A $1 \mathrm{CC}$ type tank container located on a 13-4012 flat car was chosen as a prototype. While designing the model, the following aspects were considered: the trochoidal law of motion of the disturbing action (sea waves) on the train ferry with containers, the dissipative component occurring due to the train ferry oscillations under conditions of sea rolling, the relative bearings of sea waves to the train ferry body, and the wind force to the above-water projection of the train ferry, flat car located on the upper deck and tank containers. The differential equations of motion were solved in the Mathcad with their reduction to the normal Cauchy form with subsequent integration by the Runge-Kutta method. The acceleration values obtained, as the components of the dynamic loading, were considered in the stability research for the tank container relative to the flat car frame. Findings. The author obtained the clarified values of dynamic loadings, acting on the tank container located on a flat car during the train ferry transportation. Originality. A mathematic model of displacements of a tank container located on a flat car during the train ferry transportation was developed. Practical value. The findings of the research can be used at designing tank containers of a new generation with improved technical and economical, as well as ecological indices.

Keywords: tank container; dynamics; stability; simulation; structural loading; train ferry transportation 


\section{REFERENCES}

1. Blagoveshchenskiy, S. N., \& Kholodilin, A. N. (1975). Spravochnik po statike i dinamike korablya (Vol. 1-2). Leningrad: Sudostroenie. (in Russian)

2. Veter $i$ volny v okeanakh i moryakh: spravochnye dannye. (1974). Leningrad: Transport. (in Russian)

3. Freight wagons. Requirements to structural strength and dynamic qualities, 54 GOST 33211-2014 (2016). (in Russian)

4. Konteynery dlya perevozki opasnykh gruzov. Trebovaniya po ekspluatatsionnoy bezopasnosti, 6 GOST 31232-2004 (2005). (in Russian)

5. Lovska, A. O., Fomin, O. V., Okorokov, A. M., \& Melnichuk, O. M. (2015). Research of a tank-container strength of improved construction using the computer simulation of operating conditions. Science and Transport Progress, 2(56), 180-188. doi: 10.15802/stp2015/42177 (in Ukrainian)

6. Dyakonov, V. (2000). MATHCAD 8/2000: spetsialnyy spravochnik. St. Petersburg: Piter, 2000. (in Russian)

7. Zemlezin, I. N. (1970). Metodika rascheta i issledovaniya sil, deystvuyushchikh na vagon pri transportirovke na morskikh paromakh. Moscow: Transport. (in Russian)

8. Kiryanov, D. V. (2006). Mathcad 13. St. Petersburg: BKhV-Peterburg. (in Russian)

9. Lovska, A. O. (2017). Determination of the loading of containers in mixed trains when transporting by train ferries. Science and Transport Progress, 6(72), 49-60. doi: 10.15802/stp2017/118993 (in Ukrainian)

10. Lovska, A. O. (2018). Simulation of loads for a tank container included in combined trains transported by train ferry. Bulletin of the National Technical University «KhPI». Series: Dynamics and Strength of Machines, 1(33), 28-32. doi: 10.20998/2078-9130.2018.33.151225 (in Ukrainian)

11. Lovska, A. O. (2014). Osoblyvosti matematychnoho modeliuvannia dynamiky kuzoviv vahoniv pry yikh perevezenni na zaliznychnykh poromakh. Zbirnik naukovih prac' of Donetsk Railway Transport Institute, 37, 84-93. (in Ukrainian)

12. Lugovskiy, V. V. (1976). Dinamika morya: izbrannye voprosy, svyazannye s ucheniem morekhodnosti korablya: uchebnik dlya vtuzov. Leningrad: Sudostroenie. (in Russian)

13. Makeev, S. V., \& Buylenkov, P. M. (2018). Osobennosti rascheta napryazhenno-deformirovannogo sostoyaniya tanka-konteynera s uchetom realnogo nagruzheniya v ekspluatatsii. Nauka-obrazovanie-proizvodstvo: opyt $i$ perspektivy razvitiya: sbornik materialov XIV Mezhdunarodnoy nauchno-tekhnicheskoy konferentsii, posvyashchennoy pamyati Ye. G. Zudova (8-9 fevralya 2018 g.) (Vol. 1-2). Nizhniy Tagil. (in Russian)

14. Makov, Y. L. (2007). Kachka sudov: uchebnoe posobie. Kaliningrad: Izdatelstvo FGOU VPO "KGTU". (in Russian)

15. Myamlin, S. V., Kebal, Yu. V., \& Kondratyuk, S. M. (2012). Perspektivnye konstruktsii konteynerov-tsistern dlya perevozki svetlykh nefteproduktov, ammiaka i uglevodorodnykh gazov. Zaliznychnyi transport Ukrainy, 2, 44-46. (in Russian)

16. Bogomaz, G. I., Mekhov, D. D., Pilipchenko, O. P., \& Chernomashentseva, Y. G. (1992). Nagruzhennost konteynerov-tsistern, raspolozhennykh na zheleznodorozhnoy platforme, pri udarakh v avtostsepku. In Dynamika ta keruvannia rukhom mekhanichnykh system (pp. 87-95). Kyiv: Institute of Technical Mechanics. (in Russian)

17. Nastavlenie po krepleniyu gruza dlya t/kh «Petrovsk» (2005). PR № 002SNF001-LMPL-805. Odessa: MIB. (in Russian)

18. Pravila perevozok opasnykh gruzov. K soglasheniyu o mezhdunarodnom zheleznodorozhnom gruzovom soobshchenii (SMGS) (2011). Organisation for Co-operation between Railways (OSJD). Retrieved from http://docs.cntd.ru/document/902061479 (in Russian)

19. Sukolenov, A. Y., Zakhariev, E., Gutin, I. G., \& Sukolenov, A. Y. (Ed). Mezhdunarodnaya paromnaya pereprava Ilichevsk - Varna. Moscow: Transport. (in Russian)

20. Lovska, A. O., Melnychuk, O. M., \& Fomin, O. V. (2015). Udoskonalennia konteineriv-tsystern dlia perevezennia naftoproduktiv shliakhom vprovadzhennia $\mathrm{v}$ yikh nesuchi konstruktsii kruhlykh trub. Zaliznychnyi transport Ukrainy, 1, 40-44. (in Ukrainian)

21. Fomin, O. V., \& Hostra, A. V. (2015). Variatsiine opysannia konstruktyvnykh vykonan vantazhnykh vahoniv. Zbirnyk naukovykh prats Derzhavnoho ekonomiko-tekhnolohichnoho universytetu transportu. Seriia: "Transportni systemy i tekhnolohii», 26-27, 137-147. (in Ukrainian)

22. Shmakov, M. G. (1975). Spetsialnye sudovye ustroystva: Spravochnoe posobie. Leningrad: Sudostroenie. (in Russian) 
23. Bhattacharyya, R., \& Hazra, A. (2013). A study on Stress analysis of ISO tank container. 58th Congress of The Indian Society of Theoretical and Applied Mechanics: Conference Paper. Retrieved from https://clck.ru/F9TYb (in English)

24. Lisowski, E., \& CzyĪycki, W. (2011). Transport and storage of LNG in container tanks. Journal of KONES Powertrain and Transport, 18(3), 193-201. (in English)

25. Rzeczycki, A., \& Wiśnicki, B. (2016). Strength Analysis of Shipping Container Floor with Gooseneck Tunnel under Heavy Cargo Load. Solid State Phenomena, 252, 81-90. doi: 10.4028/www.scientific.net/ssp.252.81 (in English)

26. Vatulia, G., Falendysh, A., Orel, Y., \& Pavliuchenkov, M. (2017). Structural Improvements in a Tank Wagon with Modern Software Packages. Procedia Engineering, 187, 301-307. doi: 10.1016/j.proeng.2017.04.379 (in English)

27. Trejo-Escandón, J. O., Leyva-Díaz, A., Tamayo-Meza, P. A., Flores-Herrera, L. A., \& Sandoval-Pineda, J. M. (2015). Study of the effect of liquid level on the static behavior of a tank wagon. International Journal of Engineering Research and Science and Technology, 4(1), 18-25. (in English)

28. Talu, M. (2017). The Influence of the Corrosion and Temperature on the Von Mises Stress in the Lateral Cover of a Pressurized Fuel Tank. Hidraulica, 4, 89-97. (in English)

29. Tiernan, S., \& Fahy, M. (2002). Dynamic FEA modelling of ISO tank containers. Journal of Materials Processing Technology, 124(1-2), 126-132. doi: 10.1016/s0924-0136(02)00196-6 (in English)

Надійшла до редколегії: 18.09.2018

Прийнята до друку: 15.01.2019 